\title{
Host Specificity of Pecan Strains of Xylella fastidiosa subsp. multiplex
}

\author{
R. S. Sanderlin, Louisiana State University Agricultural Center Pecan Research-Extension Station, Shreveport 71115
}

\begin{abstract}
Pecan (Carya illinoinensis) bacterial leaf scorch disease, caused by Xylella fastidiosa subsp. multiplex, causes defoliation and reduces terminal growth and nut yield. The pathogen is transmitted to pecan by xylem-feeding spittlebugs and leafhoppers and through graft transmission in the clonal propagation of cultivars. Xylella fastidiosa subsp. multiplex has a broad host range, infecting numerous hardwood tree species and some herbaceous species. There is evidence of additional host specialization within subsp. multiplex. Data presented here support the existence of host specialization with $X$. fastidiosa that infect pecan. In this study, mechanical inoculation was used to inoculate several plant species that are naturally infected by subsp. multiplex, including sycamore, red maple, purple-leafed plum, and blueberry with strains of $X$. fastidiosa from pecan. Hosts of three other

subspecies were also inoculated with the pecan strains: grapevine (subsp. fastidiosa); oleander (subsp. sandyi); and mulberry (subsp. morus). Pecan was also inoculated with a strain of the pathogen from sycamore (subsp. multiplex) and a strain from grapevine (subsp. fastidiosa). In greenhouse tests, inoculum prepared from $X$. fastidiosa obtained from naturally infected pecan almost exclusively infected pecan. In addition, the subsp. $m u l-$ tiplex strain from sycamore generally did not infect pecan, and the subsp. fastidiosa strain from grapevine did not infect pecan. The inability of the pecan strain to readily infect other hosts commonly located in the vicinity of pecan orchards affects the management recommendations for the disease in commercial pecan production by allowing management practices to focus on pecan orchards and insect vectors.
\end{abstract}

The bacterium Xylella fastidiosa (Wells et al. 1987) infects over 300 species of plants across more than 60 plant families (EFSA Panel on Plant Health 2015). It causes disease in numerous economically significant hosts, such as grapevine, peach, almond, coffee, citrus, blueberry, oleander, and many hardwood trees (Gould and Lashomb 2005; Hopkins and Purcell 2002). Generally, leaf scorching caused by xylem-plugging and pathogen-induced water stress is the primary symptom of diseases caused by this pathogen (Choi et al. 2013; Esau 1948; Hopkins 1989). The pathogen is transmitted from plant to plant by xylem-specific feeding leafhoppers and spittlebugs in the families Cercopoidae and Cicadellidae (Frazier 1965; Redak et al. 2004) and can be transmitted by grafting with infected rootstocks or scions (Hutchins et al. 1953; Sanderlin and Melanson 2006; Wester and Jylkka 1959).

At least four subspecies of $X$. fastidiosa are recognized (Schaad et al. 2004a, b; Schuenzel et al. 2005), and others have been proposed (Almeida and Nunney 2015; Randall et al. 2009; Nunney et al. 2014). Three of the subspecies are common to the southeastern United States, including Louisiana; subsp. fastidiosa causes disease in grapevine, almond, and alfalfa and infects other species, subsp. sandyi causes oleander scorch, and subsp. multiplex causes scorch diseases in numerous hardwood trees, including pecan [Carya illinoinensis (Wangenh.) C. Koch] (EFSA Panel on Plant Health 2015; Sanderlin and Heyderich-Alger 2000; Schaad et al. 2004a, b). The subspecies are distinguished by genetic differences, different plant species they can infect and produce disease in, and geographic origins (Almeida and Nunney 2015; Schaad et al. 2004a, b). It was initially believed that hosts susceptible to any strain of a subspecies would be susceptible to all of the strains within that subspecies (Schaad et al. 2004a). More recent work has demonstrated that there is additional host specialization within subspecies (Almeida et al. 2008; Almeida and Nunney 2015; Nunney et al. 2013).

In pecan, $X$. fastidiosa causes pecan bacterial leaf scorch (PBLS). Symptoms begin with brown to tan scorching at leaflet margins, usually at or near the leaflet apex. The tissue desiccation spreads basipetally and affected leaflets abscise. As the disease develops, it is common for rachises with partial or complete leaflet loss to remain attached to the stem. Symptoms generally begin in late spring and

Corresponding author: R. S. Sanderlin; E-mail: rsanderlin@agcenter.lsu.edu

Accepted for publication 6 January 2017.

() 2017 The American Phytopathological Society continue to develop with continuous defoliation throughout the summer and into the fall. Defoliation is accompanied by reduced terminal growth and yield (Sanderlin and Heyderich-Alger 2003). Until recently, the disease was believed to be limited to the southeastern United States; however, the disease has been found in pecan trees in the western U.S. production area and now poses a threat to pecan production throughout the United States (Sherman 2015).

Because subsp. multiplex infects not only pecan but also numerous trees, such as sycamore, maples, oaks, elms, Prunus species, and sweetgum, common in Louisiana and the southeastern United States (Ferrin 2009; Gould and Lashomb 2005; Nunney et al. 2013; Sherald 2007), there is the possibility that the pathogen could be insecttransmitted between species. Woodland and landscape plants often located near pecan orchards could serve as potential pathogen reservoirs and would make managing PBLS more difficult. The presence or absence of host specialization exhibited by $X$. fastidiosa strains from pecan could affect management recommendations for PBLS.

This study was conducted to determine if $X$. fastidiosa strains from pecan can infect other hosts susceptible to subsp. multiplex, as well as hosts susceptible to other subspecies of the pathogen. In addition, a $X$. fastidiosa subsp. multiplex strain from sycamore and a $X$. fastidiosa subsp. fastidiosa strain from grapevine were tested for their ability to infect pecan.

The data collected from this research provides information on the potential effectiveness of management methods for PBLS based on host ecology and vector management. These data also provide additional evidence that host specialization is common within $X$. fastidiosa subsp. multiplex.

\section{Materials and Methods}

Plants used for inoculation. Pecan trees used in all inoculations were grown from seed of a single 'Cape Fear' tree located at the Louisiana State University AgCenter Pecan Research-Extension Station orchard. Grapevine (Vitis vinifera) plants of 'Cabernet Sauvignon' and 'Chardonnay' used for inoculations in 2010 and 2011 were grown from cuttings obtained from source plants previously purchased from a nursery in Texas. Chardonnay grapevines used for inoculations in 2012 were purchased from a nursery in Georgia. Oleander (Nerium oleander) plants were grown from cuttings of 'Red Calypso' purchased from a nursery in Louisiana. Rabbiteye blueberry (Vaccinium ashei) 'Tifblue' plants were also purchased from a Louisiana nursery. The sycamore (Platanus occidentalis), red maple (Acer rubrum), purple-leafed plum (Prunus cerasifera) 'Thundercloud', and red mulberry (Morus rubra) were purchased 
from a nursery in Texas. All plants were grown, one plant per pot, in Metro Mix 902 (Sungro, Agawam, MA) potting mix and were maintained in a greenhouse. Plants were provided with water once or twice a week as dictated by greenhouse temperature. The greenhouse was cooled by evaporative cooling and greenhouse temperature varied with the outside temperature. Greenhouse temperature ranged from -5 to $45^{\circ} \mathrm{C}$ in 2011 ; from 0.3 to $40^{\circ} \mathrm{C}$ in 2012 ; and from 0.8 to $41^{\circ} \mathrm{C}$ in 2013 .

Xylella fastidiosa strains and inoculum preparation. The hostrange study of the pecan strain of $X$. fastidiosa was initiated in 2010. The single isolate of the pecan strain used for inoculations in 2010 had apparently lost its pathogenicity. Because of the lengthy nature of PBLS development, the ineffectiveness of the inoculations was not realized until late in the year after all inoculations had been made, and no data were obtained for the host range of the pecan strain of the pathogen from the 2010 inoculations.

Because of the failure of the 2010 test, a mixture of three pecan strains used in previous research was used for inoculation tests in 2011 and 2012. Strains used were XF A-05, XF B-05, and XF $\mathrm{C}-05$, originally obtained from a Cape Fear pecan tree growing at the LSU AgCenter Pecan Research-Extension Station and classified as subsp. multiplex (Melanson et al. 2012).

The sycamore strain of $X$. fastidiosa, XF A-07, was isolated from a severely diseased tree in Shreveport in 2007 and was classified as $X$. fastidiosa subsp. multiplex (Melanson et al. 2012). The grapevine strain, XF A-08, was isolated from an unknown variety of $V$. vinifera with Pierce's disease growing in Avoyelles Parish, LA, and was classified as X. fastidiosa subsp. fastidiosa (Melanson et al. 2012).

Xylella fastidiosa strains stored in $0.5 \mathrm{ml}$ of $30 \%$ glycerol were removed from storage at $-80^{\circ} \mathrm{C}$, thawed at room temperature, and plated onto modified periwinkle wilt agar (PWA) (Davis et al. $1981)$ in $100 \times 15$-mm culture plates, one vial per plate. Cultures were incubated near $28^{\circ} \mathrm{C}$ in darkness. Regenerated cultures were transferred once or twice at 10- to-14-day intervals to fresh PWA to increase bacterial growth for inoculum. Inoculum was prepared by scraping the growth from 10- to-12-day-old cultures and suspending it in sterile, molecular-grade water. Cultures of XF A-05, XF B-05, and XF C-05 were mixed for the pecan-strains inoculum. Cultures of XF A-07 and XF A-08 were used to prepare the sycamore and grapevine strain inoculum, respectively. Different storage vials were used to regenerate cultures for each inoculation date, which served as a replication.

General inoculation procedure. Prior to inoculation, all test plants were observed for symptoms of scorch disease and were tested for $X$. fastidiosa by ELISA (enzyme-linked immunological assay) using a commercial kit specific for $X$. fastidiosa (Agdia, Inc., Elkhart, IN). For preinoculation testing, three to five leaves, petioles, or rachises (depending on plant species) were collected from each plant one to four days prior to inoculation. The tissue was placed into mesh-lined plastic bags (Agdia) with cold kit extraction buffer and pulverized with a hammer. ELISA was carried out per kit instructions and absorbance was measured at $650 \mathrm{~nm}$. An absorbance of 2.5 times greater than the extraction buffer was recorded as positive for $X$. fastidiosa infection. All of the plants used in the inoculation tests were negative for X. fastidiosa in the preinoculation assays.

Prior to inoculation, each plant was pruned to a single main stem with foliage. Inoculation was into the lower portion of the current season's main-stem growth. A 10- $\mu 1$ drop of inoculum was pipetted onto the stem of the current season's growth and a dissecting needle was passed through the drop into the tissue. Five inoculum drops generally within a $10-\mathrm{cm}$ length of each other were applied to each plant and the needles left in place until the drops were absorbed into the stem. Absorption was usually rapid, but sometimes required about $2 \mathrm{~min}$. Oleander plants absorbed the inoculum the slowest. To increase inoculum absorption in oleander, the tops of these plants were cut off a few minutes before inoculation to allow sap to escape and reduce turgor pressure.

Inoculations were performed immediately after inoculum preparation and usually took between 2 and $3 \mathrm{~h}$ for inoculation with the pecan strain inoculum, and about an hour with the sycamore and grapevine strains inoculum. For all inoculations, one plant of each species in a test was inoculated and the procedure repeated until all plants of each species were inoculated.

Inoculations with the mixture of three $X$. fastidios $a$ strains from pecan were performed in 2011 and 2012. Four replications of inoculation were conducted each year. Inoculations were made on 26 June, 25 July, 18 August, and 8 September in 2011, and on 25 May, 16 June, 13 and 31 July in 2012. Concentration of the inoculation was $10^{6}$ to $10^{7} \mathrm{CFU}$ per ml as determined by dilution plate counts. Species inoculated in 2011 were pecan, plum, sycamore, blueberry, red maple, oleander, and grapevine. The same species were inoculated in 2012 with the addition of red mulberry. Five plants of each species were inoculated for each replication. For check plants, five pecan trees were inoculated with sterile, molecular-grade water at each replication.

For inoculations made with the sycamore and grapevine strains of $X$. fastidiosa, a single inoculation was done in 2010, 2011, and 2012. Inoculum concentration of the sycamore strain was $10^{6}$ to $10^{9} \mathrm{CFU}$ per $\mathrm{ml}$ and was $10^{9}$ to $10^{10} \mathrm{CFU}$ per $\mathrm{ml}$ for the grapevine strain. Inoculations with the sycamore strain were made to sycamore, pecan, and grapevine on 8 October 2010 and to sycamore, pecan, and red maple on 20 October 2011 and to sycamore, pecan, red maple, and blueberry on 27 August 2012. Inoculations with the grapevine strain were made to grapevine, pecan, and sycamore on 13 October 2010 and to grapevine and pecan on 7 October 2011 and 17 August 2012, respectively. Eight to 12 plants of each species were inoculated each year. In 2010, water-inoculated plants of sycamore (5), pecan (10), and grapevine (5) were included in the tests. No additional check plants were included in the 2011 or 2012 tests because check plants used with the pecan strain host range tests and kept in the same greenhouse were considered sufficient to detect insect transmission of the pathogen.

Postinoculation testing for infection. Following inoculation, all test plants were assayed for $X$. fastidiosa infection each year for two years. Plants in the greenhouse were routinely observed for scorch disease symptoms. Isolation of the pathogen from inoculated plants was not used as a diagnostic assay because culture of $X$. factidiosa subsp. multiplex from infected plants is problematic (Minsavage et al. 1994). All test plants were systematically assayed for infection by ELISA. The check plants were assayed once each year of the test period, and the pathogen-inoculated plants were usually tested two to four times each year unless they tested positive for infection during a previous assay within the year. Preparation of plant tissue for ELISA and the procedure was as described for the preinoculation assay. Tissue for assay was collected from mature foliage that usually developed following inoculation and was greater than $30 \mathrm{~cm}$ from the inoculated main stem site. Systematic assays were done at least two months post inoculation. Because inoculations with the sycamore and grapevine strains were done between August and October each year, ELISAs were done with the inoculated plants the following summer.

Beginning in 2011, the unused ELISA extracts still in the mesh bags with the pulverized tissue were stored at $-20^{\circ} \mathrm{C}$ for future DNA extraction for use in a polymerase chain reaction (PCR) assay for $X$. fastidiosa DNA in the plant tissue. ELISA extracts have been reported to be a viable source for DNA extraction for PCR use (Amsden et al. 2010).

For DNA extraction, the frozen ELISA extracts were thawed at room temperature, and $1.5 \mathrm{ml}$ was pipetted into a microcentrifuge tube. Following centrifugation at $16 \times \mathrm{g}$ for $30 \mathrm{~min}$, DNA was extracted from the pellets using the DNeasy Plant Mini Kit (Qiagen, Valencia, CA). Manufacturer's instructions were followed except the cell lysis period at $65^{\circ} \mathrm{C}$ was extended to $20 \mathrm{~min}$. Extracted DNA was suspended in $100 \mu \mathrm{l}$ of the kit resuspension buffer. When multiple PCR assays were conducted on individual plants, a new DNA preparation from ELISA extract was used.

A modified PCR program based on the PCR assay with the $X$. fastidiosa primers RST31 and RST33 developed by Minsavage et al. (1994) was used to test DNA extracts for the presence of $X$. fastidiosa 
using $26 \mu \mathrm{l}$ of 2X PCR Master Mix (Promega, Inc., Madison, WI), $15 \mu \mathrm{l}$ nuclease-free water, a $0.4-\mu \mathrm{M}$ concentration of each primer (Bioneer, Inc., Alameda, CA), and $5 \mu$ l of DNA. The PCR program was $95^{\circ} \mathrm{C}$ for $1 \mathrm{~min}$, then 60 cycles of $95^{\circ} \mathrm{C}$ for $30 \mathrm{~s}, 55^{\circ} \mathrm{C}$ for $30 \mathrm{~s}$, and $72^{\circ} \mathrm{C}$ for $45 \mathrm{~s}$, with a final $5 \mathrm{~min}$ extension at $72^{\circ} \mathrm{C}$ and cooling to $4^{\circ} \mathrm{C}$. Sterile distilled water was used as a negative control. DNA, extracted as previously described, from a known PBLS infected pecan tree was used as a positive control. PCR products were electrophoresed in a $1.5 \%$ agarose gel in TAE buffer. The presence of a PCR product about $733 \mathrm{bp}$ in size was considered to be a positive PCR assay for $X$. fastidiosa.

Assay results for infection with both ELISA and PCR with the same plant were sometimes variable not only with tissue samples taken at different times, but also with the same tissue samples. When this occurred, plants were given multiple assays. Instances of one ELISA or one PCR assay yielding a positive for infection coupled with multiple negative assays from the same plant may be because of the nature of the bacterium to vary in population through the growth cycle of the plant (Hopkins 1981; Hopkins et al. 1991). Also, the bacterium can be localized within diseased tissue (Holland et al. 2014; Hopkins 1981). This may result in a failure to sample tissue containing the bacterium, especially in plants with low population or when each test sample consists of a small amount of tissue. PCR can detect a lower population of the bacterium than ELISA (Minsavage et al. 1994); however, mature pecan tissue and tissue of other plant species likely contain substances, such as polyphenols and alkaloids that make extraction of small quantities of bacterial DNA problematic. Because of these possibilities, plants that gave a positive test for infection only once and multiple negative assays in the same year were recorded as infected.

In an attempt to verify that any plants infected with the pathogen were infected with the subspecies of $X$. fastidiosa used in the inoculation tests, a previously described multiprimer PCR assay designed to distinguish three subspecies of $X$. fastidiosa found in the southern United States (Hernandez-Martinez et al. 2006) was also used with DNA prepared from the frozen ELISA extracts. For this assay, each PCR reaction contained $2 \mu$ l each of primers XF1968-L, XF1968-R, XF2542-L, XF2542-R, ALM1, and ALM2, $26 \mu 1$ of 2X PCR Master Mix (Promega), $7 \mu l$ of nuclease-free water, and $5 \mu l$ of DNA preparation. Conditions for PCR and electrophoresis were the same as described above.

Statistical analysis. The GLM procedure in SAS version 9.4 (SAS Institute, Inc. Cary, NC) was used for data analysis with mean significance in the number of plants infected in each species determined by the least significant difference test. Statistical analyses were done on the combined two-year assay data for the inoculations made with the $X$. fastidiosa pecan strains; the 2011 and 2012 tests were analyzed separately. Data from the three years of inoculations with the pathogen strains from sycamore and grapevine were combined for analysis by strain.

\section{Results}

2011 inoculations using $X$. fastidiosa strains from pecan. The test plants and check trees from the 2011 inoculations were assayed between early October and mid-November 2011. Only a few ELISA extracts were stored at the time of ELISA testing and were later used for PCR assay. Seventeen of the 20 pecan trees inoculated with the $X$. fastidiosa subsp. multiplex pecan strain mixture were infected (Table 1). Infection occurred at each of the four inoculation dates, indicating that inoculum was viable at each replication. The 20 check pecan trees were negative for the bacterium. Two plum trees were positive for infection and one red maple tree tested positive by both ELISA and PCR (Table 1). Each of the 20 inoculated plants of sycamore, blueberry, oleander, and grapevine gave a negative result for $X$. fastidiosa infection (Table 1). None of the infected or noninfected plants expressed disease symptoms.

The plants inoculated in 2011 were maintained in the greenhouse and assayed again in 2012 using current season's growth. All plants were evaluated by both ELISA and PCR and for symptom development during the summer. ELISA was conducted between 3 July and 1 August. All inoculated plants that did not test positive for infection in the first ELISA of 2012 were tested at least one more time in September. ELISA was repeated a third or fourth time on plants that were positive in ELISA in 2011 but negative in the first two ELISAs of 2012. These final assays were conducted in November 2012. Twelve of the pecan trees that were infected in 2011, tested positive for the pathogen (Table 1) and 11 of these developed typical PBLS. Eight of the pecan trees consistently assayed negative for infection, indicating that infection was lost in five of the trees that were infected in 2011. The 20 check pecan trees remained negative for infection. Only one of the two plum trees that tested positive for infection in 2011 was still infected in 2012; the other 18 plum trees remained noninfected. All 20 red maple trees tested as noninfected in 2012, including the tree that produced a positive assay in 2011. One sycamore tree and one grapevine (Cabernet Sauvignon) was positive for infection in one of multiple assays in 2012 (Table 1).

With the 2011 and 2012 assays combined, five out of 120 nonpecan plants produced positive results for infection by the $X$. fastidiosa pecan strains. None of these infected plants developed scorch disease symptoms. The inoculated pecan trees had significantly more plants infected by the inoculum than any of the other species inoculated in 2011. There were no statistically significant differences in the number of infections between any of the other inoculated plant species (Table 1).

2012 inoculations using $X$. fastidiosa strains from pecan. Eighteen of the 20 pecan trees inoculated in 2012 were infected that year based on positive reactions in both ELISA and PCR (Table 2).

Table 1. Summary of 2011 host range inoculations with pecan strains of Xylella fastidiosa ${ }^{\mathrm{v}}$

\begin{tabular}{|c|c|c|c|c|c|c|c|c|c|c|c|c|c|}
\hline \multirow{2}{*}{$\begin{array}{l}\text { Inoculated } \\
\text { plants }\end{array}$} & \multicolumn{2}{|c|}{$\begin{array}{c}\text { ELISA (+) } \\
\text { onlyw }^{\mathrm{w}}\end{array}$} & \multicolumn{2}{|c|}{$\begin{array}{l}\text { ELISA (-) } \\
\text { only }\end{array}$} & \multicolumn{2}{|c|}{$\begin{array}{l}\text { ELISA (+) } \\
\text { PCR }(+)\end{array}$} & \multicolumn{2}{|c|}{$\begin{array}{l}\text { ELISA (+) } \\
\text { PCR (-) }\end{array}$} & \multicolumn{2}{|c|}{$\begin{array}{l}\text { ELISA (-) } \\
\text { PCR (+) }\end{array}$} & \multicolumn{2}{|c|}{$\begin{array}{l}\text { ELISA (-) } \\
\text { PCR }(-)\end{array}$} & \multirow{2}{*}{$\begin{array}{c}\text { Total no. infected/total } \\
\text { no. inoculated }\end{array}$} \\
\hline & $2011^{x}$ & 2012 & 2011 & 2012 & 2011 & 2012 & 2011 & 2012 & 2011 & 2012 & 2011 & 2012 & \\
\hline Pecan $^{y}$ & 12 & $-^{z}$ & 2 & - & 4 & 10 & 1 & 0 & 0 & 2 & 1 & 8 & $17 / 20 \mathrm{a}$ \\
\hline Plum & 1 & - & 18 & - & 0 & 0 & 1 & 0 & - & 1 & - & 19 & $2 / 20 b$ \\
\hline Sycamore & 0 & - & 20 & - & - & 0 & - & 0 & - & 1 & - & 19 & $1 / 20 \mathrm{~b}$ \\
\hline Blueberry & 0 & - & 20 & - & - & 0 & - & 0 & - & 0 & - & 20 & $0 / 20 \mathrm{~b}$ \\
\hline Red Maple & 0 & - & 19 & - & 1 & 0 & - & 0 & 0 & 0 & - & 20 & $1 / 20 \mathrm{~b}$ \\
\hline Oleander & 0 & - & 20 & - & - & 0 & - & 0 & - & 0 & - & 20 & $0 / 20 \mathrm{~b}$ \\
\hline Grapevine & 0 & - & 20 & - & - & 0 & - & 0 & - & 1 & - & 19 & $1 / 20 \mathrm{~b}$ \\
\hline
\end{tabular}

v Plants were mechanically inoculated with a mixture of three strains of $X$. fastidiosa from pecan. Means followed by the same letter within a column are not significantly different $(P<0.0001)$ by the least significant difference test. All check plants tested negative for infection in all tests performed each year.

${ }^{w}$ ELISA only = Plants assayed for infection with ELISA only.

$\mathrm{x}$ Year that plants were assayed for infection.

y Pecan trees were grown from cultivar Cape Fear seed; plum trees were purple-leafed plum cultivar Thundercloud; blueberry plants were cultivar Tifblue; oleander plants were cultivar Santa Rosa; and grapevines were cultivars Chardonnay or Cabernet Sauvignon. Sycamore and red maple trees were grown from nursery seedlings.

${ }^{\mathrm{z}}$ Categories of assay in which no plants were tested are designated by -. 
Sixteen of these infected trees expressed PBLS symptoms during 2012. ELISA was conducted between the first week of September and the first week of November 2012; PCR using DNA extracted from the frozen ELISA extracts was conducted in 2015. In 2012, all of the plants in the other seven species that were inoculated tested negative for $X$. fastidiosa (Table 2), and none of these plants developed scorch disease symptoms.

In 2013, only eight of the pecan trees that were infected in 2012 tested positive for infection by ELISA and PCR; the other 12 inoculated pecan trees tested negative for infection in both assays (Table 2). PBLS was observed in four of the eight infected trees. The ELISA tests were conducted in September and October. In both the 2012 and 2013 assays, the 20 check pecan trees were noninfected.

All other plants again tested as noninfected in 2013, with the exception of one plum tree. No scorch was observed on this plum. Of the inoculated 20 plants in each of seven species susceptible to $X$. fastidiosa infection, only one plum was infected with the pecan strains of the bacterium in the 2012 inoculation test. The pecan trees inoculated in 2012 had significantly more plants infected than any of the other inoculated species. There were no significant differences in the number of plants infected between the other seven inoculated species (Table 2).

Combined results of the 2011 and 2012 host-range inoculation tests with the $X$. fastidiosa strains from pecan suggest that the pecan strains of this pathogen used in this study are host-specific. About $2 \%$ of the nonpecan plants were infected, compared with $87.5 \%$ of the inoculated pecan, and no disease symptoms were observed in the nonpecan plants. In both the 2011 and 2012 inoculation tests, no additional infected pecan trees were identified the year after inoculations took place. On the other hand, three of the six nonpecan infected plants were detected in the year following inoculation but not in the year of inoculation.

Sycamore strain inoculations. Over the three years that the sycamore strain of $X$. fastidiosa was used in inoculations, 23 of 32 sycamores assayed as infected (Table 3 . Two of 29 pecan trees were infected with the sycamore strain but without symptoms. None of the inoculated grapevine, red maple, or blueberry plants were infected, and the check plants were not infected (Table 3). The sycamore trees had a significantly higher number of plants infected with the sycamore strain inoculum than any of the other species (Table 3). The results suggest that the sycamore strain of the pathogen has the capacity to occasionally infect pecan, at least through the utilized mechanical inoculation procedure.

Grapevine strain inoculations. The grapevine strain of $X$. fastidiosa infected 23 of 28 grapevines inoculated from 2010 to 2012 (Table 4). The infected grapevines died within 12 months of inoculation. No infections were recorded in the inoculated pecan or sycamore trees, or in the check trees (Table 4).

Multiprimer PCR. The multiprimer PCR assay using DNA preparations from the ELISA extracts failed to produce reliable results.
Nonspecific binding with noninfected host plant DNA occurred frequently with pecan, sycamore, plum, and grapevine samples with the PCR conditions used in this work.

\section{Discussion}

Inoculum prepared from three pecan strains of $X$. fastidiosa was used to mechanically inoculate several known hosts of the bacterium

Table 3. Summary of host range inoculations with a strain of Xylella fastidiosa from sycamore ${ }^{\mathrm{x}}$

\begin{tabular}{lcccc}
\hline Host $^{\mathbf{y}}$ & $\mathbf{2 0 1 0}^{\mathbf{z}}$ & $\mathbf{2 0 1 1}$ & $\mathbf{2 0 1 2}$ & Three year total \\
\hline Sycamore & $7 / 10$ & $5 / 10$ & $11 / 12$ & $23 / 32 \mathrm{a}$ \\
Pecan & $0 / 9$ & $1 / 10$ & $1 / 10$ & $2 / 29 \mathrm{~b}$ \\
Grapevine & $0 / 8$ & - & - & $0 / 8 \mathrm{~b}$ \\
Red Maple & - & $0 / 10$ & $0 / 10$ & $0 / 20 \mathrm{~b}$ \\
Blueberry & - & - & $0 / 8$ & $0 / 8 \mathrm{~b}$
\end{tabular}

${ }^{\mathrm{x}}$ The numerator is the number of plants that were infected with $X$. fastidios and the denominator is the number of plants that were inoculated. Results of all ELISA and PCR assays were combined. Means followed by the same letter within a column are not significantly different $(P<0.0001)$ by the least significant difference test. All plants used as checks tested negative for infection.

${ }^{y}$ Grapevines inoculated in 2010 were three plants of cultivar Cabernet Sauvignon and five plants of cultivar Chardonnay. Pecan trees were grown from cultivar Cape Fear seed and blueberry plants were cultivar Tifblue. Sycamore and red maple trees were grown from nursery seedlings.

${ }^{\mathrm{z}}$ Year that plants were inoculated. Plants inoculated in 2010 were not assayed by PCR.

Table 4. Summary of host range inoculations with a strain of Xylella fastidiosa from grapevine ${ }^{\mathrm{x}}$

\begin{tabular}{lcccc}
\hline Host $^{\mathbf{y}}$ & $\mathbf{2 0 1 0}^{\mathbf{z}}$ & $\mathbf{2 0 1 1}$ & $\mathbf{2 0 1 2}$ & Three year total \\
\hline Grapevine & $8 / 8$ & $5 / 10$ & $10 / 10$ & $23 / 28 \mathrm{a}$ \\
Pecan & $0 / 10$ & $0 / 10$ & $0 / 10$ & $0 / 30 \mathrm{~b}$ \\
Sycamore & $0 / 10$ & - & - & $0 / 10 \mathrm{~b}$ \\
\hline
\end{tabular}

${ }^{\mathrm{x}}$ The numerator in the number of plants that were infected with $X$. fastidiosa, and the denominator is the number of plants that were inoculated. Results of all ELISA and PCR assays were combined. Means followed by the same letter within a column are not significantly different $(P<0.0001)$ by the least significant difference test. All plants used as checks tested negative for infection.

y Grapevine plants inoculated in 2010 were three plants of cultivar Cabernet Sauvignon and five plants of cultivar Chardonnay. In 2011 and 2012 all grapevine plants were cultivar Chardonnay. Pecan trees were grown from cultivar Cape Fear seed and sycamore trees were grown from nursery seedlings.

${ }^{\mathrm{z}}$ Year that plants were inoculated. Plants inoculated in 2010 were not assayed by PCR.

Table 2. Summary of 2012 host range inoculations with pecan strains of Xylella fastidiosa ${ }^{\mathrm{w}}$

\begin{tabular}{|c|c|c|c|c|c|c|c|c|c|}
\hline \multirow{2}{*}{$\begin{array}{l}\text { Inoculated } \\
\text { Plants }\end{array}$} & \multicolumn{2}{|c|}{$\begin{array}{l}\text { ELISA (+) } \\
\text { PCR }(+)\end{array}$} & \multicolumn{2}{|c|}{$\begin{array}{l}\text { ELISA (+) } \\
\text { PCR }(-)\end{array}$} & \multicolumn{2}{|c|}{$\begin{array}{l}\text { ELISA (-) } \\
\text { PCR (+) }\end{array}$} & \multicolumn{2}{|c|}{$\begin{array}{l}\text { ELISA (-) } \\
\text { PCR }(-)\end{array}$} & \multirow{2}{*}{$\begin{array}{c}\text { Total No. Infected/Total } \\
\text { No. Inoculated }\end{array}$} \\
\hline & $2012^{x}$ & 2013 & 2012 & 2013 & 2012 & 2013 & 2012 & $\overline{2013}$ & \\
\hline Pecan $^{y}$ & 18 & 8 & 0 & 0 & 0 & 0 & 2 & 12 & $18 / 20 \mathrm{a}$ \\
\hline Plum & 0 & 0 & 0 & 0 & 0 & 1 & 20 & 19 & $1 / 20 \mathrm{~b}$ \\
\hline Sycamore & 0 & 0 & 0 & 0 & 0 & 0 & 20 & 20 & $0 / 20 \mathrm{~b}$ \\
\hline Blueberry & 0 & 0 & 0 & 0 & 0 & 0 & 20 & 20 & $0 / 20 \mathrm{~b}$ \\
\hline Red Maple & 0 & 0 & 0 & 0 & 0 & 0 & 20 & 20 & $0 / 20 \mathrm{~b}$ \\
\hline Oleander & 0 & 0 & 0 & 0 & 0 & 0 & 20 & 20 & $0 / 20 \mathrm{~b}$ \\
\hline Grapevine & 0 & 0 & 0 & 0 & 0 & 0 & 20 & 20 & $0 / 20 \mathrm{~b}$ \\
\hline Red Mulberryz & 0 & 0 & 0 & 0 & 0 & 0 & 20 & 19 & $0 / 20 b$ \\
\hline
\end{tabular}

${ }^{\text {w }}$ Plants were mechanically inoculated with a mixture of three strains of $X$. fastidiosa from pecan. Means followed by the same letter within a column are not significantly different $(P<0.0001)$ by the least significant difference test. All check plants tested negative for infection in all tests performed each year.

$x$ Year that plants were assayed for infection.

y Pecan trees were grown from cultivar Cape Fear seed; plum trees were purple-leafed plum cultivar Thundercloud; blueberry plants were cultivar Tifblue; oleander plants were cultivar Santa Rosa; and grapevines were cultivar Chardonnay. Sycamore, red maple, and red mulberry plants were grown from nursery seedlings.

z One red mulberry plant died prior to testing for X. fastidiosa infection in 2013. 
to evaluate the host range of pecan strains of this pathogen. Inoculated plant species that are naturally infected by $X$. fastidiosa subsp. multiplex were pecan, sycamore, red maple, purple-leafed plum, and blueberry. Grapevine, infected by $X$. fastidiosa subsp. fastidiosa, and oleander, infected by $X$. fastidiosa subsp. sandyi were also inoculated with the pecan strains. Red mulberry was included in the inoculations in one year; a new subspecies, subsp. morus, has been proposed for strains of $X$. fastidiosa infecting mulberry (Nunney et al. 2014). Similar results were obtained from both years that inoculations were performed with the pecan strains. In 2011 and 2012, 85\% and 90\%, respectively, of the inoculated pecan trees tested positive for infection in the year of inoculation; however, infection was retained in only $71 \%$ and $44 \%$ of the trees the year following inoculation for pecan trees inoculated in 2011 and 2012, respectively. Of the other species inoculated with the pecan strains over the two year period, only three purple-leafed plums, one sycamore, one red maple, and one grapevine tested positive for infection in either the year of inoculation or the following year. None of these six plants developed disease symptoms. These results indicate that few of the $X$. fastidiosa susceptible plants other than pecan were infected when mechanically inoculated with the strains of $X$. fastidiosa from pecan.

The inability of the pecan strains of $X$. fastidiosa subsp. multiplex to infect grapevine and oleander is not surprising. In nature, grapevine is infected by $X$. fastidiosa subsp. fastidiosa and oleander by $X$. fastidiosa subsp. sandyi. Most reports have indicated that there is distinct separation of susceptible plants by subspecies (Schaad et al. 2004a, b). Xylella fastidiosa subsp. sandyi from oleander was not able to infect grapevine or oak by mechanical inoculation (Purcell et al. 1999), which are typically susceptible to infection by X. fastidiosa subsp. fastidiosa and subsp. multiplex, respectively (Schaad et al. 2004a, b). Peach seedlings inoculated with $X$. fastidiosa from grapevine did not become infected (Wells et al. 1983). Strains from sweetgum and purple-leafed plum did not infect grapevine or oleander, and $X$. fastidiosa from grapevine or oleander did not cause disease in sweetgum (Hernandez-Martinez et al. 2009). There are a few studies that have illustrated that some plant hosts can be infected by more than one subspecies of $X$. fastidiosa in nature. The strain of $X$. fastidiosa associated with olive quick decline syndrome in Italy, classified as subsp. pauca, has also been found to naturally infect almond and oleander in the area of infected olive orchards (Cariddi et al. 2014; Mang et al. 2016; Saponari et al. 2013). In the United States, almond is naturally infected by two other subspecies, fastidiosa and multiplex (Almeida and Purcell 2003); oleander is infected by subsp. sandyi (Schuenzel et al. 2005); and olive is infected by subsp. multiplex (Krugner et al. 2014). Recent work demonstrated that blueberry plants, which are typically infected by $X$. fastidiosa subsp. multiplex, can also be infected and become diseased when mechanically inoculated with $X$. fastidiosa subsp. fastidiosa from grapevine (Oliver et al. 2015). Nonetheless, most research supports host specificity across subspecies in nature; when such infections were recorded, they were often temporary (Almeida and Nunney 2015).

Host specialization observed across subspecies of the pathogen was also supported by genomic analysis using multilocus sequence typing (MLST). MLST results indicated the absence of homogenization across subspecies of $X$. fastidiosa despite the coexistence of subspecies in geographic areas (Nunney et al. 2013). Nevertheless, it is not possible to predict which plants can be infected by a particular subspecies, as illustrated by the fact that subspecies are able to infect plants belonging to different taxonomic orders; experimental work is necessary to identify hosts of the subspecies and of specific strains of the pathogen (Almeida and Nunney 2015; Nunney et al. 2013).

Cross-inoculation studies within subspecies of $X$. fastidiosa suggest a lack of host specialization within $X$. fastidiosa subsp. fastidiosa (Schaad et al. 2004a, b). But there have been demonstrations of apparent host specialization within subsp. pauca and multiplex. Strains of subsp. pauca isolated from citrus and coffee in Brazil could not infect the reciprocal host by mechanical inoculation (Almeida et al. 2008), and the subsp. pauca strain found in olive in Italy does not infect citrus (Mang et al. 2016). Within subsp. multiplex, there was reciprocal host specificity between strains from American elm and sycamore (Sherald 1993). The overall inability of the pecan strains of the pathogen to infect other plant species commonly infected by $X$. fastidiosa subsp. multiplex suggests that the pecan strains may have a high degree of host specificity. Pecans also could not be infected with a $X$. fastidiosa subsp. fastidiosa strain from grapevine, and only two of 29 pecans were infected with a $X$. fastidiosa subsp. multiplex strain from sycamore, adding to the possibility of strain specificity for pecan infection.

MLST identified three phylogenetic clusters within $X$. fastidiosa subsp. multiplex - almond, peach, and oak — and supported host specialization within subsp. multiplex (Nunney et al. 2013). The one pecan strain included in the MLST study had partial sequence type alignment with the oak group. In the data reported here, inoculum made from three strains of $X$. fastidiosa from pecan when inoculated into three other species that also have sequence type alignments in the oak group - purple-leafed plum, sycamore, and red maple — did not readily infect these species. Sycamore had the same sequence type as pecan (ST8) (Nunney et al. 2013). Only one sycamore was infected with the pecan strain inoculum and two pecan trees were infected with the sycamore strain by mechanical inoculation, suggesting that there is additional host specialization below the level detected by the current MLST protocol used for X. fastidiosa.

Plants that tested positive for infection in the year of inoculation, but which repeatedly assayed negative the year after inoculation, apparently had lost infection over the winter. The greenhouse was heated through December each year, but heat was not supplied beginning in January to allow the plants to reach dormancy. In a study with grapevine (Feil and Purcell 2001) a temperature of $5^{\circ} \mathrm{C}$ reduced the population of $X$. fastidiosa, and cumulative hours below $5^{\circ} \mathrm{C}$ were correlated with reduced population in sycamore tree shoots (Henneberger et al. 2004). Furthermore, infection in potted grapevines did not survive as well in California in colder winter locations compared with warmer winter sites (Purcell 1980). At the location of the study reported here, from January through February 2012 there were 24 days with temperatures of $5^{\circ} \mathrm{C}$ or less and nine days with temperatures of $0^{\circ} \mathrm{C}$ or less (www.usclimatedata.com). Similarly, from January through February 2013 there were 34 days with temperatures of $5^{\circ} \mathrm{C}$ or less and 11 days with temperatures of $0^{\circ} \mathrm{C}$ or less (www.usclimatedata.com). These temperatures may have resulted in the recovery from infection of the potted test plants.

The lack of symptom development in 2011 in the infected pecan trees inoculated that summer was atypical. In previous work with $X$. fastidiosa in pecan, visible symptoms usually began to appear about eight weeks post-inoculation by mechanical inoculation or insect vectors (Sanderlin 2015; Sanderlin and Melanson 2010). The pecan trees in 2011 had adequate time (three to five months) after inoculation for disease to develop before dormancy. The primary environmental anomaly in 2011 was hotter-than-average summer months, which affected greenhouse temperature. The average monthly temperatures from June through August were 3.1, 2.8, and $4.8^{\circ} \mathrm{C}$ above average, respectively; in addition, there were six days of $38^{\circ} \mathrm{C}$ or higher in September (www.usclimatedata.com). The increase in temperature may have prevented symptom expression in 2011. The possible effect of high temperature on symptom development in this test is supported by typical PBLS symptom development on infected pecan trees inoculated in 2012 (16 of 18 trees), with closer-to-average summer temperatures.

Plants positive for infection were also tested by a modified multiprimer PCR protocol (Hernandez-Martinez et al. 2006) that distinguished X. fastiodiosa subsp. fastidiosa, subsp. multiplex, and subsp. sandyi using three sets of primers. It was determined that multiprimer PCR successfully identified the pecan strains as $X$. fastidiosa subsp. multiplex using DNA from in vitro cultures with the PCR conditions used in this study, and in a previous study (Melanson et al. 2012). Nonetheless, the multiprimer PCR with the conditions used in this study failed in assays using DNA extracted from frozen ELISA extracts. Multiprimer PCR assays with frozen ELISA extracts of noninfected plants indicated that nonspecific binding was common with pecan, sycamore, grapevine, and purple-leafed plum plants. This nonspecific binding may have been the result of using a different PCR program than used by Hernandez-Martinez et al. (2006). Even 
though the multiprimer PCR assay utilized in this study was not useful for identifying $X$. fastidiosa infections to subspecies from tissue extracts, the data support the conclusion that infections were the result of the inoculations because no noninoculated plants maintained in the greenhouse were identified as being infected.

The specificity of the pecan strains of the pathogen has management implications for commercial pecan producers. If the strains that cause disease in pecan cannot infect other plant species, management efforts can be focused on pecan trees and insect vectors in pecan orchards. Although several hosts of $X$. fastidiosa subsp. multiplex, such as sycamore, plum, and red maple, and hosts of other subspecies including red mulberry and native grapevine, grow naturally in the vicinity of pecan orchards, they should not serve as reservoirs of the pecan pathotype. Blueberry scorch caused by $X$. fastidiosa is detrimental to rabbiteye blueberries grown commercially in Louisiana (Ferguson et al. 2015). The failure of the pecan strains to infect rabbiteye blueberry in this test indicates that the two crops can be managed separately for disease even if grown near each other. Even though $X$. fastidiosa may not be vector-transmitted between hosts tested in this study, some of these plants could serve as reproductive hosts for vectors, which could increase vector populations in nearby pecan orchards.

Grasses and numerous other plant species growing in the vicinity of pecan orchards have not been screened as possible hosts of the pecan strain of $X$. fastidiosa. In grape vineyards in California and Florida, it has been documented that some naturally growing plants can serve as repositories of the pathogen and serve as a pathogen source for primary infection into vineyards (Hopkins and Adlerz 1988; Hopkins and Purcell 2002; Purcell et al. 1999). Although their role is not yet defined, several plant species naturally growing near olive orchards in Italy have been identified as hosts of the strain of X. fastidiosa infecting olive trees (Saponari et al. 2014). Other plant species that often occur in the vicinity of Louisiana pecan orchards should be evaluated to determine if these plants affect infection in the orchards.

Because insect transmission of the pathogen in pecan orchards is likely from other pecan trees or possibly other Carya spp. within or near orchards, it may be possible to reduce PBLS spread by eliminating these sources of the pathogen and by using insecticides to reduce vector populations during the spring months when they are usually at their peak populations (Sanderlin et al. 2009). These management methods have not been tested, but the possibility of a pecanspecific pathotype of $X$. fastidiosa should make the application of these procedures more practical and should increase the chances of successful management of this chronic disease.

The lack of symptom development, loss of infection, occasional opposite results between serological and PCR assays, and variable results with repeated assays of the same plants indicate the need for using multiple diagnostic procedures for determining the status of infection with $X$. fastidiosa. A weakness of the work reported here is that only three pecan strains were used in the inoculations, which may not provide sufficient data on the overall potential of $X$. fastidiosa in pecan to infect other hosts. Additional testing with more pecan strains from a broader geographic area is needed to verify the true nature of host specificity in pecans.

\section{Acknowledgments}

I thank Rebecca A. Melanson, Mississippi State University Central Research and Extension Center, for numerous discussions and suggestions during the course of this work and for invaluable assistance in the preparation of this manuscript. I also acknowledge the efforts of two anonymous reviewers that have improved the quality of the manuscript. This work was funded by the Louisiana State University Agricultural Center.

\section{Literature Cited}

Almeida, R. P. P., Nascimento, F. E., Chau, J., Prado, S. S., Tsai, C.-W., Lopes, S. A., and Lopes, R. S. 2008. Genetic structure and biology of Xylella fastidiosa strains causing disease in citrus and coffee in Brazil. Appl. Environ. Microbiol. 74: 3690-3701.

Almeida, R. P. P., and Nunney, L. 2015. How do plant diseases caused by Xylella fastidiosa emerge? Plant Dis. 99:1457-1467.

Almeida, R. P. P., and Purcell, A. H. 2003. Biological traits of Xylella fastidiosa strains from grapes and almonds. Appl. Environ. Microbiol. 69:7447-7452.
Amsden, B. F., Vincelli, P, and Hartman, J. R. 2010. Real-time PCR detection of Xylella fastidiosa is independent of sample storage time and temperature. Plant Path. Fact Sheet PPFS-MISC-04. Univ. of Kentucky, Lexington.

Cariddi, C., Saponari, M., Boscia, D., De Stradis, A., Loconsole, G., Nigro, F., Porcelli, F., Potere, O., and Martelli, G. 2014. Isolation of a Xylella fastidiosa strain infecting olive and oleander in Apulia, Italy. J. Plant Pathol. 96:425-429.

Choi, H.-K., Iandolino, A., da Silva, F. G., and Douglas, R. C. 2013. Water deficit modulates the response of Vitis vinifera to the Pierce's disease pathogen Xylella fastidiosa. Mol. Plant-Microbe Interact. 643-657.

Davis, M. J., French, W. J., and Schaad, N. W. 1981. Axenic culture of the bacteria associated with phony disease of peach and plum leaf scald. Curr. Microbiol. 6:309-314.

EFSA Panel on Plant Health. 2015. Scientific opinion on the risks to plant health posed by Xylella fastidiosa in the EU territory, with the identification and evaluation of risk reduction options. EFSA J. 13:3989.

Esau, K. 1948. Anatomic effects of the viruses of Pierce's disease and phony peach. Hilgardia 18:423-482.

Feil, H., and Purcell, A. H. 2001. Temperature-dependent growth and survival of Xylella fastidiosa in vitro and in potted grapevines. Plant Dis. 85:1230-1234.

Ferguson, M. H., Clark, C. A., and Smith, B. J. 2015. Xylella fastidiosa in rabbiteye blueberry: Detection of the bacterium and association with yield loss. HortScience 50:S123.

Ferrin, D. 2009. Bacterial leaf scorch of landscape trees. Disease Identification and Management Series, Agric. Center Pub. 3132. Louisiana Plant Pathol., Louisiana State Univ., Baton Rouge, LA.

Frazier, N. W. 1965. Xylem viruses and their insect vectors. Pages 91-99 in: Proc. Int. Conf. on Virus and Vector on Perennial Hosts, with Special Reference to Vitis. Univ. of Calif. Div. Agric. Sci., Davis, CA.

Gould, A. B., and Lashomb, J. H. 2005. Bacterial leaf scorch of shade trees. 2007. APS Features doi:10.1094/APSnetFeature/2005-1105.

Henneberger, T. S. M., Stevenson, K. L., Britton, K. O., and Chang, C. J. 2004. Distribution of Xylella fastidiosa in sycamore associated with low temperature and host resistance. Plant Dis. 88:951-958.

Hernandez-Martinez, R., Cooksey, D. A., and Wong, F. P. 2009. Leaf scorch of purple-leafed plum and sweetgum dieback: Two new diseases in southern California caused by Xylella fastidiosa strains with different host ranges. Plant Dis. 93:1131-1138.

Hernandez-Martinez, R., Costa, H. S., Dumenyo, C. K., and Cooksey, D. A. 2006 Differentiation of strains of Xylella fastidiosa infecting grape, almonds, and oleander using a multiprimer PCR assay. Plant Dis. 90:1382-1388.

Holland, R. M., Christiano, R. S. C., Gamliel-Atinsky, E., and Scherm, H. 2014. Distribution of Xylella fastidiosa in blueberry stem and root sections in relation to disease severity in the field. Plant Dis. 98:443-447.

Hopkins, D. L. 1981. Seasonal concentration of the Pierce's disease bacterium in grapevine stems, petioles, and leaf veins. Phytopathology 71:415-418.

Hopkins, D. L. 1989. Xylella fastidiosa: Xylem-limited bacterial pathogen of plants. Annu. Rev. Phytopathol. 27:271-290.

Hopkins, D. L., and Adlerz, W. C. 1988. Natural hosts of Xylella fastidiosa in Florida. Plant Dis. 72:429-431.

Hopkins, D. L., Bistline, F. W., and Russo, L. W. 1991. Seasonal fluctuation in the occurrence of Xylella fastidiosa in root and stem extracts from citrus with blight. Plant Dis. 75:145-147.

Hopkins, D. L., and Purcell, A. H. 2002. Xylella fastidiosa: Cause of Pierce's disease of grapevine and other emergent diseases. Plant Dis. 86:1056-1066.

Hutchins, L. M., Cochran, L. C., and Turner, W. F. 1953. Transmission of phony peach virus from the tops of certain affected peach and plum trees. Phytopathology 43:691-696.

Krugner, R., Sisterson, M. S., Chen, J., Stenger, D. C., and Johnson, M. W. 2014. Evaluation of olive as a host of Xylella fastidiosa and associated sharpshooter vectors. Plant Dis. 98:1186-1193.

Mang, S., Frisullo, S., Eishafie, H., and Camele, I. 2016. Diversity evaluation of Xylella fastidiosa from infected olive trees in Apulia (Southern Italy). Plant Pathol. J. 32:102-111.

Melanson, R. A., Sanderlin, R. S., McTaggart, A. R., and Ham, J. H. 2012. A systemic study reveals that Xylella fastidiosa strains from pecan are part of X. fastidiosa subsp. multiplex. Plant Dis. 96:1123-1134.

Minsavage, G. V., Thompson, C. M., Hopkins, D. L., Leite, R. M. V. B. C., and Stall, R. E. 1994. Development of a polymerase chain reaction protocol for detection of Xylella fastidiosa in plant tissue. Phytopathology 84:456-461.

Nunney, L., Schuenzel, E. L., Scally, M., Bromley, R. E., and Stouthamer, R. 2014. Large-scale intersubspecific recombination in the plant-pathogenic bacterium Xylella fastidiosa is associated with the host shift to mulberry. Appl. Environ. Microbiol. 80:3025-3033.

Nunney, L., Vickerman, D. B., Bromley, R. E., Russell, S. A., Hartman, J. R., Morano, L. D., and Stouthamer, R. 2013. Recent evolutionary radiation and host plant specialization in the Xylella fastidiosa subspecies native to the United States. Appl. Environ. Microbiol. 79:2189-2200.

Oliver, J. E., Corbine, P. A., and De La Fuente, L. 2015. Xylella fastidiosa isolates from both subsp. multiplex and fastidiosa cause disease on southern highbush blueberry (Vaccinium sp.) under greenhouse conditions. Phytopathology 105: 855-862.

Purcell, A. H. 1980. Environmental therapy for Pierce's disease of grapevines Plant Dis. 64:388-390. 
Purcell, A. H., Saunders, S. R., Hendson, M., Grebus, M. E., and Henry, M. J. 1999. Causal role of Xylella fastidiosa in oleander leaf scorch disease. Phytopathology 89:53-58.

Randall, J. J., Goldberg, N. P., Kemp, J. D., Radionenko, M., French, J. M., Olsen, M. W., and Hanson, S. F. 2009. Genetic analysis of a novel Xylella fastidiosa subspecies found in the southwestern United States. Appl. Environ. Microbiol. 75:5631-5638.

Redak, R. A., Purcell, A. H., Lopes, J. R. S., Blua, M. J., Mizell, R. F., III, and Andersen, P. C. 2004. The biology of xylem fluid-feeding insect vectors of Xylella fastidiosa and their relation to disease epidemiology. Annu. Rev. Entomol. 49:243-270.

Sanderlin, R. S. 2015. Susceptibility of some common pecan rootstocks to infection by Xylella fastidiosa. HortScience 50:1183-1186.

Sanderlin, R. S., and Heyderich-Alger, K. I. 2000. Evidence that Xylella fastidiosa can cause leaf scorch disease of pecan. Plant Dis. 84:1282-1286.

Sanderlin, R. S., and Heyderich-Alger, K. I. 2003. Effects of pecan bacterial leaf scorch on growth and yield components of cultivar Cape Fear. Plant Dis. 87:259-262.

Sanderlin, R. S., Li, B., Melanson, R. A., and Gil, S. 2009. Spread of Xylella fastidiosa in a pecan orchard and presence of potential vectors in orchards. Phytopathology 99:S114.

Sanderlin, R. S., and Melanson, R. A. 2006. Transmission of Xylella fastidiosa through pecan rootstock. HortScience 4:1455-1456.

Sanderlin, R. S., and Melanson, R. A. 2010. Insect transmission of Xylella fastidiosa to pecan. Plant Dis. 94:465-470.

Saponari, M., Boscia, D., Loconsole, G., Palmisano, F., Savino, V., Potere, O., and Martelli, G. P. 2014. New hosts of Xylella fastidiosa strain CoDiRO in Apulia. J. Plant Pathol. 96:611.

Saponari, M., Boscia, D., Nigro, F., and Martelli, G. 2013. Identification of DNA sequences related to Xylella fastidiosa in oleander, almond and olive trees exhibiting leaf scorch symptoms in Apulia (Southern Italy). J. Plant Pathol. 95:668.
Schaad, N. W., Postnikova, E., Lacy, G., Fatmi, M. B., and Chang, C. J. 2004a. Xylella fastidiosa subspecies: $X$. fastidiosa subsp. piercei, subsp. nov., $X$ fastidiosa subsp. multiplex subsp. nov., and $X$. fastidiosa subsp. pauca subsp. nov. Syst. Appl. Microbiol. 27:290-300.

Schaad, N. W., Postnikova, E., Lacy, G., Fatmi, M. B., and Chang, C. J. 2004b. Xylella fastidiosa subspecies: $X$. fastidiosa subsp. piercei, subsp. nov., $X$. fastidiosa subsp. multiplex subsp. nov., and $X$. fastidiosa subsp. pauca subsp. nov. (Erratum) Syst. Appl. Microbiol. 27:763.

Schuenzel, E. L., Scally, M., Stouthamer, R., and Nunney, L. 2005. A multigene phylogenetic study of clonal diversity and divergence in North American strains of the plant pathogen Xylella fastidiosa. Appl. Environ. Microbiol. 71: 3832-3839.

Sherald, J. L. 1993. Pathogenicity of Xylella fastidiosa in American elm and failure of reciprocal transmission between strains from elm and sycamore. Plant Dis. 77:190-193.

Sherald, J. L. 2007. Bacterial leaf scorch of landscape trees: What we know and what we do not know. Arboricult. Urban For. 33:376-385.

Sherman, J. 2015. Bacterial leaf scorch identified in Arizona; survey launched Pecan S. Mag. 48:50-52.

Wells, J. M., Raju, B. C., Hung, H. Y., Weisburg, W. G., Mandelco-Paul, L., and Brenner, D. J. 1987. Xylella fastidiosa gen. nov., sp, nov: gram-negative, xylem-limited, fastidious plant bacteria related to Xanthomonas spp. Int. J. Syst. Bacteriol. 37:136-143.

Wells, J. M., Raju, B. C., and Nyland, G. 1983. Isolation, culture, and pathogenicity of the bacterium causing phony disease of peach. Phytopathology 73:859-862.

Wester, H. V., and Jylkka, E. W. 1959. Elm leaf scorch, graft transmissible virus of American elm. Plant Dis. Rep. 43:519. 